\title{
The Indicators of M\&A or Green Field Investment Behavior: the Evidence from Power Industry
}

\author{
Zhang Qiusheng Ye Guanghui Chen Yunhua \\ Center for China M\&A Research, Beijing Jiaotong University, P.R.China
}

\begin{abstract}
:
M\&A and green field investment (GFI) are very important methods of company growth. Each of the investment ways could bring different outstanding achievement and development of company, so it is very important to choose the way of investment. This paper discusses the boundary of M\&A and green field investment both in external and internal levels, and then uses power industry data to build a decision model of M\&A-green field investment in power industry.
\end{abstract}

Keywords: M\&A, Green field investment boundary, Logistic model, Hydropower

\section{Introduction}

The expanding of company could be carried out through two ways: one is internal growth, and the other is external growth. The company gets the aim of internal growth by integrating internal resources and raises resource efficiency, while achieving external growth by absorbing external resources. Both internal growth and external growth have advantages. Green field investment (GFI) is one of the most typical ways of internal growth and M\&A is the one of external growth, meanwhile GFI and M\&A also are very universal ways of company investment. Each of the investment ways could bring different outstanding achievements and development of company, so it is very important to decide the investment ways. This paper discusses the boundary of M\&A and GFI behaviors both in external and internal levels, and then uses power industry data to build a decision model of M\&AGFI in power industry.

\section{Literature Review}

Most of traditional study on M\&A and GFI focus on activities of multinational. These literatures believe that the foreign investor could get the certain resource in low cost by M\&A and GFI. (Hymer, 1976; Caves, 1971) But these papers nearly not tell the different effects on multinational of M\&A and GFI.

Some Chinese academics analyze the influential factors to make the decision of cooperation investment and the choice between GFI and M\&A. But most of these studies focus on the multinational transaction and on the point of the incentives of multinational investment or merger. The differences between GFI and M\&A and their theoretical explanations will be analyzed later.

Statistical techniques for analyzing the influential factors of M\&A or GFI decision have been used in many literatures. The quantitative empirical study almost shows some certain influential factors are very important to make the decision of company investment manner.

Andrade and Stafford (1999) investigated the economic role of mergers. They performed a comparative study of mergers and internal corporate investment from analyzing investment activities of 2969 USA companies. They find strong evidence that merger activity clusters through time by industry, whereas internal investment does not. Mergers play both an "expansionary" and "concretionary" role in industry restructuring. During the 1970 s and 1980s, excess capacity drove industry consolidation through mergers, while peak capacity utilization triggered industry expansion through non-merger investments. In the 1990s, this phenomenon was reversed, as industries with strong growth prospects, high profitability, and near capacity experience the most intense merger activity.

Some investigations from the point of institution classified the company as localization and globalization. (Rosenzweig and Singh, 1991; Haveman, 1993; Davis,2000). Harzing (2002) 
did a further research by analyzing 287 samples from 21 countries, considering the different structure and enterprise strategy of the company and its subsidiaries. The conclusion is that the localization trends to choose merger for the purpose of low-level integration and the highlevel local reaction, meanwhile, the globalization trends to choose GFI.

Based on the forecast by Bal Krishnan and Koza (1991, 1993), when target and investment company are in the different industries, it seems a best choose to do the GFI for the low transaction costs.

An investigation showed that the convertibility of resource is most important influential factor to make M\&A or GFI decision. When considering culture shock, the foreign company would like to merge the local company (Jemison and Sitkin, 1986).
Following the investigation of these early literatures, we can find that most of them focused on a certain factors which influence the company investment decision. This study integrates with previous quantitative empirical study results, and uses the power industry data to analyze the influential factors of hydropower investment.

\section{Factors influencing $M \& A$ and GFI}

Power industry is tested in the empirical study of this paper. The following influential factors are very important to power investment, and these factors as external factors and internal factors are defined based on our analytical research and previous studies. The factors and their indicators are shown in the Table 1.

Table 1: External and Internal Factors of Investment Behavior

\begin{tabular}{|c|c|c|c|}
\hline & $\begin{array}{l}\text { Influential } \\
\text { Factors }\end{array}$ & Indicators & Definitions \\
\hline \multirow{3}{*}{$\begin{array}{l}\text { External } \\
\text { Factors }\end{array}$} & $\begin{array}{l}\text { Market Growth } \\
\text { Rate }\end{array}$ & $\begin{array}{l}\text { Market Growth } \\
\text { Rate }\end{array}$ & $\begin{array}{l}\mathrm{V}(\mathrm{IMS})=(\text { total sales of industry in the year of } \\
\text { investment happened - total sales of industry in the } \\
\text { year of investment happened two years before / total } \\
\text { sales of industry in the year of investment happened } \\
\text { two years before })\end{array}$ \\
\hline & $\begin{array}{c}\text { Market } \\
\text { Competition }\end{array}$ & Market Intensity & $\begin{array}{c}\mathrm{V}(\mathrm{MI})=\text { total sales of the biggest eight firms/the total } \\
\text { sales of industry*100 }\end{array}$ \\
\hline & $\begin{array}{l}\text { Regional } \\
\text { Advantages }\end{array}$ & $\begin{array}{l}\text { Difference of } \\
\text { purchase power }\end{array}$ & $\begin{array}{l}\mathrm{V}(\mathrm{DP})=\text { purchase power of country of acquiring firm } \\
\text { /nominal exchange rate of country of acquiring firm - } \\
\text { purchases power of country of acquired firm /nominal } \\
\text { exchange rate of country of acquired firm }\end{array}$ \\
\hline \multirow{7}{*}{$\begin{array}{l}\text { Internal } \\
\text { Factors }\end{array}$} & $\begin{array}{l}\text { Conversion } \\
\text { Property of } \\
\text { resource }\end{array}$ & $\begin{array}{l}\text { Intangible Asset } \\
\text { Rate }\end{array}$ & $\mathrm{V}(\mathrm{IAR})=$ Intangible Asset/total assets \\
\hline & $\begin{array}{l}\text { Enterprise } \\
\text { Strategy }\end{array}$ & $\begin{array}{l}\text { International } \\
\text { Strategy }\end{array}$ & $\mathrm{V}(\mathrm{IS})=0$, when globalization; 1 , when localization \\
\hline & $\begin{array}{l}\text { The Major } \\
\text { Business } \\
\text { Diversification }\end{array}$ & $\begin{array}{c}\text { Degree of } \\
\text { product } \\
\text { diversification } \\
\end{array}$ & $\begin{array}{l}V(D P D)=\text { the number of major business which take } \\
20 \% \text { of sales }\end{array}$ \\
\hline & $\begin{array}{c}\text { M\&A } \\
\text { experience }\end{array}$ & $\begin{array}{l}\text { Merger cases } \\
\text { before }\end{array}$ & $\mathrm{V}(\mathrm{MAE})=$ the number of enterprise have been acquired \\
\hline & $\begin{array}{l}\text { Enterprises } \\
\text { Scale }\end{array}$ & Market share & $\mathrm{V}(\mathrm{MS})=$ company sales /industry sales \\
\hline & $\begin{array}{l}\text { Enterprise } \\
\text { Management } \\
\text { Level } \\
\end{array}$ & ROE & $\begin{array}{c}\mathrm{V}(\mathrm{ROE})=\text { Average return on equity during the past } 3 \\
\text { years } * 100\end{array}$ \\
\hline & $\begin{array}{l}\text { Social Culture } \\
\text { Difference }\end{array}$ & $\begin{array}{l}\text { Multinational } \\
\text { Investment }\end{array}$ & $\begin{array}{c}\mathrm{SCD}=1 \text { if international investment; } 0 \text { if domestic } \\
\text { investment }\end{array}$ \\
\hline
\end{tabular}

\section{Data}

The power industry data are extracted from ZEPHYR M\&A database of Bureau van Dijk, which is the renowned financial data bank in Europe. In 1990s, power industry entered free market in Europe and northern America, which is earlier than that in any other regions. For the completely competition, the investment is more 
flourishing and the data is more integrated in Europe and northern America in1990s. This study extracts power industry data of Europe and northern America from 1999-2004 to establish the model, in order to analyze the decision of M\&A and GFI. This study adopts 194 samples, including 94 samples of M\&A and 100 of GFI, to fulfill the requirement.

\section{The decision model of M\&A and GFI}

The econometric tool used in this section is the logistic regression, which is designed specifically to analyze the determinants of discrete dependent variables, as is the case with our events. The study creates 10 dependent variables to establish the Logistic regression, which are Market Growth Rate, Market Intensity,
Difference of purchase power, Intangible Asset Rate, International Strategy, Degree of product diversification, Merger cases before, Market share, ROE, Multinational Investment.

The Logistic regression:

$\mathrm{Y}=1$, if $\mathrm{M} \& \mathrm{~A}$ event, else 0

$$
\begin{aligned}
& E\left(y_{i}\right)=\varphi_{i}=f\left(\beta_{0}+\beta_{1} x_{i 1}+\beta_{2} x_{i 2}+\ldots . .+\beta_{10} x_{i 10}\right) ? \\
& \mathrm{i}=1,2, \ldots \ldots 194 \\
& \mathrm{f}(\mathrm{x})=\frac{\mathrm{e}^{\mathrm{x}}}{1+\mathrm{e}^{\mathrm{x}}} \\
& \mathrm{E}\left(\mathrm{y}_{\mathrm{i}}\right)=\frac{\exp \left(\beta_{0}+\beta_{1} x_{i 1}+\ldots . .+\beta_{10} x_{i 10}\right)}{1+\exp \left(\beta_{0}+\beta_{1} x_{i 1}+\ldots . .+\beta_{10} x_{i 10}\right)}, \\
& i=1,2, \ldots . .10, \mathrm{p}=1,2, \ldots \ldots . .194 ? \mathrm{C}
\end{aligned}
$$

\begin{tabular}{|c|c|c|c|c|c|c|c|}
\hline & & $\mathrm{B}$ & $S . E_{1}$ & wiald & df & Sig. & Exa(B) \\
\hline \multirow{5}{*}{$\begin{array}{l}\text { Step } \\
1^{a} \\
\text { Step } \\
2^{b}\end{array}$} & $x 8$ & 11.234 & 26.574 & .179 & 1 & .672 & 75638.51 \\
\hline & Constant & -1.966 & .285 & 47.472 & 1 & .000 & .140 \\
\hline & $x 8$ & 11.178 & 26.666 & .176 & 1 & .675 & 71557.04 \\
\hline & $\times 10(1)$ & -2.593 & .967 & 7.193 & 1 & .007 & .07 \\
\hline & Constant & .405 & .913 & .197 & 1 & .657 & 1.500 \\
\hline \multirow{4}{*}{$\begin{array}{l}\text { Step } \\
3^{c}\end{array}$} & $\times 8$ & 11.237 & 26.555 & .179 & 1 & .672 & 75858.64 \\
\hline & $x 9$ & -.009 & .005 & 3.673 & 1 & .055 & .991 \\
\hline & $\times 10(1)$ & -3.555 & 1.212 & 8.607 & 1 & .000 & .029 \\
\hline & Constant & 1.380 & 1.163 & 1.409 & 1 & .235 & 3.977 \\
\hline \multirow{5}{*}{$\begin{array}{l}\text { Step } \\
4\end{array}$} & $\times 5$ & 3.747 & 2.120 & 3.123 & 1 & .077 & 42.394 \\
\hline & $\times 8$ & 11.301 & 26.471 & .182 & 1 & .669 & 80897.83 \\
\hline & $x 9$ & -.009 & .005 & 3.853 & 1 & .050 & .991 \\
\hline & $\times 10(1)$ & -3.805 & 1.237 & 9.463 & 1 & .002 & .022 \\
\hline & Constant & 1.383 & 1.170 & 1.397 & 1 & .237 & 3.985 \\
\hline \multirow{6}{*}{$\begin{array}{l}\text { Step } \\
5\end{array}$} & $\times 2$ & -.031 & .018 & 3.029 & 1 & .082 & .969 \\
\hline & $\times 5$ & 4.597 & 2.240 & 4.212 & 1 & .040 & 99.211 \\
\hline & $x 8$ & 11.468 & 26.499 & .187 & 1 & .665 & 95624.51 \\
\hline & $\times 9$ & -.009 & .005 & 3.722 & 1 & .054 & .991 \\
\hline & $\times 10(1)$ & -3.813 & 1.316 & 8.394 & 1 & .004 & .022 \\
\hline & Constant & 3.631 & 1.834 & 3.921 & 1 & 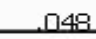 & 37.744 \\
\hline
\end{tabular}

\section{Result and Findings}

Table 2 Variables in the Equation

a. Variable(s) entered on step 1: $x 8$.

b. Variable(s) entered on step 2: $\times 10$.

c. Variable(s) entered on step $3: \times 9$.

d. Variable(s) entered on step 4: $\times 5$.

e. Variable(s) entered on step 5: $\times 2$.

Table 3 Model Summary

\begin{tabular}{|l|c|c|c|}
\hline Step & $\begin{array}{c}-2 \text { Log } \\
\text { likelihood }\end{array}$ & $\begin{array}{c}\text { Cox \& Snell } \\
\text { R Square }\end{array}$ & $\begin{array}{c}\text { Nagelkerke R } \\
\text { Square }\end{array}$ \\
\hline 1 & 84.928 & .606 & .809 \\
2 & 78.039 & .620 & .828 \\
3 & 73.392 & .629 & .840 \\
4 & 70.759 & .634 & .847 \\
5 & 67.837 & .640 & .854 \\
\hline
\end{tabular}


Table 4 Classification Table

\begin{tabular}{|c|c|c|c|c|c|}
\hline & & & \multicolumn{3}{|c|}{$\begin{array}{c}\text { Predicted } \\
\end{array}$} \\
\hline & & & \multicolumn{2}{|c|}{$\begin{array}{c}\text { 发生并购或投资交易 } \\
\text { 行为 }\end{array}$} & \multirow{2}{*}{$\begin{array}{l}\text { Percentage } \\
\text { Correct }\end{array}$} \\
\hline & \multicolumn{2}{|l|}{ Observed } & 0 & 1 & \\
\hline \multirow[t]{3}{*}{ Step 1} & 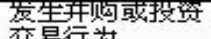 & 0 & 100 & 0 & 100.0 \\
\hline & $-\infty+\infty 1\lrcorner \beta$ & 1 & 14 & 74 & 84.1 \\
\hline & Overall Percentage & & & & 92.6 \\
\hline \multirow[t]{3}{*}{ Step 2} & 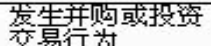 & 0 & 98 & 2 & 98.0 \\
\hline & 2ळ1」今 & 1 & 11 & 77 & 87.5 \\
\hline & Overall Percentage & & & & 93.1 \\
\hline \multirow[t]{3}{*}{ Step 3} & 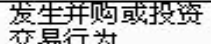 & 0 & 98 & 2 & 98.0 \\
\hline & $x-211 / 1$ & 1 & 11 & 77 & 87.5 \\
\hline & Overall Percentage & & & & 93.1 \\
\hline \multirow[t]{3}{*}{ Step 4} & 菻生并购或投粱 & 0 & 98 & 2 & 98.0 \\
\hline & $x \gg 1 」$ & 1 & 11 & 77 & 87.5 \\
\hline & Overall Percentage & & & & 93.1 \\
\hline \multirow[t]{3}{*}{ Step 5} & 营生并购或投染 & 0 & 99 & 1 & 99.0 \\
\hline & $x=21]$ & 1 & 11 & 77 & 87.5 \\
\hline & Overall Percentage & & & & 93.6 \\
\hline
\end{tabular}

a. The cut walue is .500

Based on the Logistic regression analysis (table2, table 3 and table 4), this study concludes the following results:

(1) The model could be used to forecast investment behavior in power industry.

(2) There are five indexes, including external factors : $\mathrm{X}_{2}$ market intensity, and intern factors: $\mathrm{X}_{10}$ Culture Shock, $\mathrm{X}_{5}$ Intangible Asset Rate, $\mathrm{X}_{9}$ Enterprise Management level, and $\mathrm{X}_{8}$ Enterprise Merger Experience. They all enter into the final decision model.

(3) Indicators like Market growth rate, Enterprise scale, International Strategy are not in the final model. It shows that these factors don't have important influence on the decision between M\&A and GFI in power industry.

(4) M\&A and GFI decision model:

$\mathrm{E}\left(\mathrm{y}_{\mathrm{i}}\right)=\frac{\exp \left(-0.182-0.031 x_{2}+4.597 x_{5}+11.468 x_{8}{ }^{-0.009} x_{9}{ }^{-3.813} x_{10}\right)}{1+\exp \left(-0.182-0.031 x_{2}+4.597 x_{5}+11.468 x_{8}{ }^{-0.009} x_{9}{ }^{-3.813} x_{10}\right)}$

$\mathrm{E}(\mathrm{Yi})<0.5$ enterprise likely to choose GFI

$\mathrm{E}(\mathrm{Yi})>0.5$ enterprise likely to choose $\mathrm{M} \& \mathrm{~A}$

\section{Conclusion}

Based on the empirical study, there are several findings on the decision between M\&A and GFI in power industry. The choice appears to be influenced by Market Intensity, the external variable and internal factors, including Culture Shock, Intangible Asset Rate, and Enterprise Management. In particular, more company culture difference between the investor and target market increases higher integration risk, as well as the firms would like to choose GFI strategy. Furthermore, if market intensity is high, firms are likely to choose GFI. A related conclusion is that it appears to be possible to make relatively good prediction of M\&A using variable merger experience. There is also a very useful conclusion that with the higher enterprise management level, the enterprise is more likely to choose the GFI strategy. Last but not least, if a company has more Intangible Asset, it tends to expand itself by $\mathrm{M} \& \mathrm{~A}$.

\section{Reference}

[1] Hymer, S. H. (1976). The International Operations of National Firms. MIT Press. pp3346

[2] Andrade, Gregor, Erik Stafford. (1999). Investigating the Economic Role of Mergers, Harvard Business School working paper

[3] Rosenzweig P. M, Singh J. V.1991. Organizational environments and the multinational enterprise. Academy of Management Review. 16(2):340-361

[4] Jemison, D.B., and Sitkin, S.B. (1986). Acquisitions: The process can be a problem. Harvard Business Review: March, 107-116

[5] John H. Dunning ed. (1995). Multinational Enterprises, Economic Structure and International Competitiveness, Wiley/IRM, Genena

[6] Joskow, P. L., Schmaleness, R. (1983). Markets for Power. MIT press

[7] Qiusheng Zhang, Dong Wang. (2001) Company Mergers and Acquisitions, Northern Jiaotong University Press. pp272-273(in Chinese) 